\title{
PENTINGNYA SEJARAH BAGI GENERASI MUDA
}

\author{
Dana Rizki Firdaus \\ 1810111110004 \\ Email : danarizki4@gmail.com \\ Program Studi Pendidikan Sejarah Fakultas Keguruan dan Ilmu Pendidikan \\ Universitas Lambung Mangkurat \\ Banjarmasin
}

\begin{abstract}
Abstrak
Generasi milenial di era global saat ini berpikir sangat realistis, sementara sejarah adalah peristiwa masa lalu, yang menurut mereka sudah berlalu dan berakhir. Tetapi sejarah juga menggambarkan masa lalu suatu bangsa, dan itu terkait dengan apa yang sudah dicapai, kejayaan, atau kemunduran. Bahkan lembaran hitam atau putih serta kesuksesan maupun kegagalan yang dialaminya di masa lampau. Dengan mempelajari sejarah para generasi muda bisa mendapatkan banyak hal, salah satunya dengan pelajaran masa lampau yang dijadikan rederensi kedepan agar tidak jatuh pada lubang yang sama. Sebagai generasi muda juga dituntut agar terus melestarikan sejarah sebagaimana kata bung Karno yang terkenal “Jas Merah” jangan sekali-kali lupakan sejarah.
\end{abstract}

\section{PENDAHULUAN}

Indonesia merupakan negara majemuk yang kaya akan sejarah dan kebudayaan. Namun, sekarang kita dihadapkan pada persoalan rendahnya minat generasi muda terhadap sejarah. Sejarah sering kali dianggap sebagai hal yang membosankan dan tidak menarik. Adanya perkembangan zaman yang begitu pesat, sejarah seperti dilupakan dan disangkal. Banyak yang berpikiran, sejarah identik dengan belajar masa lalu. Pasalnya, sejarah berperan penting dalam pendidikan generasi milenial. Lantas, mengapa sejarah itu penting untuk dipelajari oleh generasi milenial? 
Sejarah adalah hal penting bagi suatu bangsa, jika suatu bangsa memiliki sejarah maka bangsa tersebut akan mudah bangkit karena memiliki pegangan yang kuat. Sejarah juga sebagai pembelajaran, karena dengan sejarah bisa belajar kesalahan-kesalahan yang pernah dilakukan dimasa lalu. Sejarah tidak hanya ada dan tidak dipelajari tetapi ada untuk jadi pembelajaran, sebuah sejarah itu adalah pembelajaran bukan warisan. Sebab warisan yang bekerja adalah yang mewariskan bukan yang diwariskan (Anis, 2015 : 53).

Sebagai generasi muda, sudah seharusnya memiliki pemahaman sejarah. Dengan memiliki pemahaman sejarah maka generasi muda bisa mengetahui asal usul mereka dan mereka tau sejarah mereka dari mana. "Jangan lupakan sejarah” begitu lah yang disampaikan bung karno yang kita kenal sampai saat ini. Sejarah perjuangan Indonesia, adalah kontiunitas, dari suatu perjuangan generasi yang satu kepada kegenerasi selanjutnya yang akan melanjutkan. (Aminullah, 2017:142)

\section{Pengertian Sejarah dan Generasi Muda}

Pengertian sejarah banyak sekali, secara substansi sejarah adalah sebuah ilmu tetang aktivitas manusia dalam rentang waktu, dalam artian bahwa manusia selalu mengalami dinamika dan perubahan secara terus menerus (Anis, 2015: 54). Sejarah adalah cerita tentang peristiwa masa lampau yang benar-benar terjadi, bahwa sebuah peristiwa yang terjadi dan benar-benar terjadi di masa lampau. (Hugiono dkk,1991:1). Jadi sejarah yang bisa saya simpulkan adalah peristiwa masa lampau yang benar benar terjadi, dan setiap zaman meiliki cerita atau sejarah nya masing-masing.

Generasi muda adalah generasi yang memiliki karakter. Karakter dimaknai sebagai cara berpikir dan berperilaku yang khas tiap individu untuk hidup dan bekerja sama dalam lingkup keluarga, masyarakat, bangsa, dan negara (Samani \& Hariyanto, 2016, 41). Karakter tersebut diperlukan oleh bangsa karena karakter seperti itu yang memiliki kesadaran akan bangsa Indonesia kedepannya agar menjadi yang lebih baik khususnya dalam pemahaman sejarah.

\section{Pentingnya Sejarah bagi Generasi Muda}


Generasi muda merupakan salah satu komponen yang perlu dilibatkan dalam pembangunan diberbagai aspek. Hal tersebut disebabkan generasi muda adalah hal yang potensial sehingga dapat mendukung keberhasilan. Potensi generasi muda yang dimaksud adalah bahwa generasi muda adalah generasi yang memiliki pengetahuan baru, inovatif, dan kreatif yang dapat digunakan untuk membangun bangsa. Hal tersebut sesuai yang diungkapkan Safrin (2016) peran generasi pemuda sangat dibutuhkan mengingat bahwa pemuda sebagai tonggak perubahan. Pemuda menjadi faktor penting karena semangat juangnya yang tinggi, solusinya yang kreatif, serta perwujudan mereka yang inovatif. Sebagai penerus bangsa, pemuda harus mampu melakukan perannya dalam berbagai bidang, termasuk bidang sejarah.

Ketika pemuda sudah memiliki pemahaman sejarah maka sejarah akan menjadi hal yang sangat baik bagi generasi muda karena dengan sejarah mereka bisa belajar banyak hal. Salah satu pelajaran yang berperan vital dalam penanaman nilai-nilai karakter bagi generasi muda dalam upaya membangun ideologi dan rasa nasionalisme untuk pembangunan jati diri dan karakter bangsa adalah sejarah. Sejarah mengajarkan bagaimana menyelesaikan masalah pada masa lalu, yang bisa dilakukan dimasa sekarang. Sejarah juga menjadi contoh Ketika perjuangan para pahlawan yang luar biasa dalam membela bangsa Indonesia dalam melawan penjajah dan memperjuangkan kemerdekaan, hal ini bisa didapatkan oleh generasi muda jika mereka belajar sejarah. Sangat disayangkan jika sejarah yang diajarkan oleh pendidik disekolah tidak dilakukan dengan maksimal, pada umumnya orang berpendapat bahwa pelajaran sejarah adalah pelajaran yang tidak penting. Hapalan, tugas dan ditambah pendidik mengajar yang kurang memanfaatkan media untuk menarik minat siswa dalam pembelajaran sejarah. Sejarah diartikan bukan hanya sebagai rangkaian peristiwa melainkan lingkaran peristiwa yang terentang dalam lilitan gagasan. Dalam artian, gagasan yang dimaksud merupakan dasar dari semua tindakan dan berada di belakang setiap kejadian sehingga peristiwa itu dianggap penting. (Anis, $2013: 150$ )

Sebagai peristiwa yang telah berlalu, tentu saja sejarah dianggap oleh masyarakat secara umum 'suatu hal yang tidak up to date', apabila hal itu dipandang dari sudut nilainilai yang matrialistis, tetapi jangan lupa bahwa kejadian atau peristiwa masa lampau umat manusia yang dijadikan sejarah itu merupakan yang menentukan untuk masa selanjutnya. 
Sebagai contoh peristiwa masa Kolonial, Pergerakan Nasional dengan organisasi pergerakan, dan seterusnya merupakan konsep-konsep yang dibangun dari peristiwa-peristiwa sejarah. Semua peristiwa-peristiwa yang lahir pada masa itu dilahirkan dengan secara sadar oleh mereka (tokoh-tokoh) yang sadar akan kehidupan dan nasib bangsanya pada masa itu, sehingga mereka berbuat dan melakukan tindakan-tindakan sesuai dengan kemampuan yang dimilikinya pada waktu itu. Banyak orang seringkali lupa bahwa peristiwa masa lampau (sejarah) sangat penting bagi kelanjutan kehidupan masa depannya, sehingga sejarawan mengemukakan bahwa sejarah itu mempunyai tiga dimensi, yaitu masa lampau, masa kini ini, dan masa yang akan datang.

Sejarah juga termasuk hal yang penting bagi generasi muda, dalam artian mereka juga perlu mengetahui budaya-budaya yang ada di Indonesia. Karena jika dikaitkan dengan sejarah, maka biasanya banyak diminati oleh kelompok yang sudah tua. Maka dalam hal ini perlu dilakukan pengemasan yang tepat dalam menyampaikan sejarah bagi generasi muda, agar mereka tertarik mempelajari sejarah, termasuk sejarah terkait budaya asli Indonesia, guna memperkuat pengetahuan generasi muda tentang budaya dan sejarah negeri tercinta. Jika tidak memiliki kesadaran kita tidak akan pernah tahu kenapa bangsa ini ada, sehingga kita akan kehilangan identitas dan kita menjadi bangsa yang sakit. Kondisi ini mungkin sedang terjadi, sehingga kita menjadi galau tentang identitas (Anis, $2016: 491$ )

Pada era yang canggih dan modern ini, tidak semestinya generasi muda lupa akan pentingnya memahami dan mempelajari proses sejarah. Dengan perkembangan zaman justru anak muda bisa belajar sejarah dengan visualisasi yang bagus, seperti film film sejarah yang sudah diadopsi dari buku. Tetapi di satu sisi kita juga perlu literasi sejarah agar daya olah pikir kita semakin kritis dan terbentuk, karena dalam peristiwa sejarah perlu menyulut imajinasi, sehingga mendorong kita untuk berpikir lebih luas dan mengumpulkan lebih banyak informasi. Kita juga bisa mengetahui nilai yang terkandung pada suatu peristiwa, jadi secara tidak langsung akan membentuk kepribadian kita menjadi lebih baik. Sejarah juga bukan hanya tentang perjuangan maupun keterpurukan, bisa juga untuk menyelidiki perubahan atau peristiwa yang terjadi di sekitar kita.

Maka dari itu, golongan muda sangat penting untuk memahami sejarah, khusunya sejarah bangsanya dari masa ke masa. Kalaupun generasi muda suatu bangsa tidak 
mengetahui sejarah bangsanya sendiri, kemana generasi milenial ingin membawa bangsanya? Padahal memahami sejarahlah kita dapat mengetahui tujuan dan ideologi bangsa kita sendiri.

\section{SIMPULAN}

Sebagai Generasi muda sudah sepatutnya memiliki kesadaran sejarah, karena sejarah suatu bangsa ada dipundak pemuda. Dengan perkembangan zaman sekarang harusnya pemuda akan sangat terbantu karena mempelajari sejarah bisa melalui banyak cara. Kesadaran sejarah menginformasikan kepada kita akan menghargai jasa para pahlawan yang suda mereflesikan hidupnya sebagai etos bangsa (Anis, 2016: 493). Hal ini lah yang diperlukan bangsa kita agar sejarah memiliki banyak minat khususnya pada generasi muda.

Kesadaran sejarah harus dipelajari dari sejak bangku sekolah, bagaimana siswa belajar sejarah disekolah dengan baik dan benar yang dibantu oleh tenaga pendidik dengan memanfaatkan kemajuan teknologi guna menarik minat peserta didik dalam pembelajaran sejarah. Maka dalam hal ini perlu dilakukan pengemasan yang tepat dalam menyampaikan sejarah bagi generasi milenial, agar mereka tertarik mempelajari sejarah, termasuk sejarah terkait budaya asli Indonesia, guna memperkuat pengetahuan generasi muda tentang budaya dan sejarah negeri tercinta. Bahkan seiring perkembangan zaman yang berubah dari waktu ke waktu, hingga kita sampai pada era milenial ini banyak sekali terdapat tantangan-tantangan bagi generasi saat ini dan regenerasi selanjutnya.

Sebab itu jangan pernah lupakan sejarah, terutama sejarah bangsa kita sendiri walaupun konteks zamannya yang sudah berbeda, karena bangsa terbentuk dari sejarah yang luar biasa sangatlah tidak mudah perjuangannya.

\section{REFERENSI}

Anis, M. Z. A. (2015). Sejarah Bukan Warisan Melainkan Pembelajaran. 
Anis, M. Z. A. (2016). Sejarah, Kesadaran Sejarah dan Pupusnya Identitas Nasional.

Anis, M. Z. A. (2013). ILMU SEJARAH SEBAGAI SUMBER PEMBELAJARAN IPS. Mewacanakan Pendidikan IPS, 149.

Amirullah, A. (2017, February). Pentingnya Sejarah Dalam Pembinaan Karakter Bangsa Dan Pembangunan Nasional. In Prosiding Seminar Nasional Himpunan Sarjana Ilmu-ilmu Sosial (Vol. 2, pp. 141-148).

Samani, Muchlas \& Hariyanto. (2016). Konsep dan Model Pendidikan Karakter. Bandung: PT Remaja Rosdakarya.

Safrin, Muhammad. (2016). Peran Generasi Muda Menghadapi MEA (Masyarakat Ekonomi Asean). [Online], http://www.kompasiana.com/safrin/peran-generasi- mudamenghadapi-mea-masyarakat-ekonomiasean_56bed50fcc92738b11e2330d, diakses 24 april 2021. 